\title{
The recombinant pea defensin Drr230a is active against impacting soybean and cotton pathogenic fungi from the genera Fusarium, Colletotrichum and Phakopsora
}

\author{
Ariane Ferreira Lacerda ${ }^{1,2} \cdot$ Rafael Perseghini Del Sarto ${ }^{1,3} \cdot$ \\ Marilia Santos Silva ${ }^{1}$ - Erico Augusto Rosas de Vasconcelos ${ }^{1}$. \\ Roberta Ramos Coelho ${ }^{1}$ - Vanessa Olinto dos Santos ${ }^{1,2}$. \\ Claudia Vieira Godoy ${ }^{4}$. Claudine Dinali Santos Seixas ${ }^{4}$. \\ Maria Cristina Mattar da Silva ${ }^{1} \cdot$ Maria Fatima Grossi-de-Sa ${ }^{1,5}$
}

Received: 13 April 2015/Accepted: 13 June 2015/Published online: 13 February 2016

(c) The Author(s) 2016. This article is published with open access at Springerlink.com

\begin{abstract}
Plant defensins are antifungal peptides produced by the innate immune system plants developed to circumvent fungal infection. The defensin Drr230a, originally isolated from pea, has been previously shown to be active against various entomopathogenic and phytopathogenic fungi. In the present study, the activity of a yeast-expressed recombinant Drr230a protein (rDrr230a) was tested against impacting soybean and cotton fungi. First, the gene was subcloned into the yeast expression vector pPICZaA and expressed in Pichia pastoris. Resulting rDrr230a exhibited in vitro activity against fungal growth and spore germination of Fusarium tucumaniae, which causes soybean sudden death syndrome, and against Colletotrichum gossypii var. cephalosporioides, which causes cotton ramulosis. The $\mathrm{rDrr} 230 \mathrm{a} \mathrm{IC}_{50}$ corresponding to inhibition of fungal growth of $F$. tucumaniae and C. gossypii var. cephalosporioides was 7.67 and $0.84 \mu \mathrm{M}$, respectively, demonstrating moderate activity against $F$. tucumaniae and high potency against $C$. gossypii var.
\end{abstract}

Maria Fatima Grossi-de-Sa

fatima.grossi@embrapa.br

1 Embrapa Recursos Genéticos e Biotecnologia, PqEB, Avenida W5 Norte (Final), PO 02372, Brasília, DF 70770-917, Brazil

2 Universidade Federal do Rio Grande do Norte, Avenida Senador Salgado Filho 3000, Lagoa Nova, Natal, RN 59078-970, Brazil

3 Centro Universitário do Distrito Federal, SEP/SUL EQ 704/ A12 904 Conjunto A, Brasília, DF 70390-045, Brazil

4 Embrapa Soja, Rodovia Carlos João Strass, Distrito de Warta, A10 PO Box 231, Distrito de Warta, PR 86001-970, Brazil

5 Universidade Católica de Brasília, SGAN 916 Módulo B Avenida W5, Brasília, DF 70790-160, Brazil cephalosporioides. Additionally, rDrr230a at $25 \mathrm{ng} / \mu \mathrm{l}$ $(3.83 \mu \mathrm{M})$ resulted in $100 \%$ inhibition of spore germination of both fungi, demonstrating that rDrr230a affects fungal development since spore germination. Moreover, rDrr230a at $3 \mu \mathrm{g} / \mu \mathrm{l}(460.12 \mu \mathrm{M})$ inhibited $100 \%$ of in vitro spore germination of the obligatory biotrophic fungus Phakopsora pachyrhizi, which causes Asian soybean rust. Interestingly, rDrr230a substantially decreased the severity of Asian rust, as demonstrated by in planta assay. To our knowledge, this is the first report of a plant defensin active against an obligatory biotrophic phytopathogenic fungus. Results revealed the potential of rDrr230a as a candidate to be used in plant genetic engineering to control relevant cotton and soybean fungal diseases.

Keywords Defensin - Pisum sativum - Pichia pastoris . Fusarium tucumaniae - Colletotrichum gossypii var. cephalosporioides $\cdot$ Phakopsora pachyrhizi

\section{Introduction}

Plant diseases caused by fungi affect a broad range of crops worldwide, being responsible for significant losses and for the decrease in quality and safety of agricultural products. In crop plants, fungi cause more economic damage than any other group of microorganisms, with annual losses estimated at more than US\$200 billion (Horbach et al. 2011). There are several fungal diseases impacting in tropical areas, which include cotton ramulosis, Asian soybean rust and soybean sudden death syndrome caused by Colletotrichum gossypii (South) var. cephalosporioides A. S. Costa, Phakopsora pachyrhizi H. \& P. Syd., and Fusarium solani (Mart.) Sacc. f. sp. glycines (= Fusarium tucumaniae T.) (Aoki et al. 2003), respectively. Currently, 
there are no cotton or soybean varieties with good agronomic traits, which at the same time present high resistance against these important diseases. In addition, none of these diseases are satisfactorily controlled by fungicides.

To circumvent fungal infection, plants have developed innate immune systems that recognize the presence of pathogens and initiate effective defense responses (Muthamilarasan and Prasad 2013). Therefore, plants produce diverse molecules such as carbohydrates, lipids (Rojas et al. 2014), antimicrobial enzymes (Habib and Fazili 2007), secondary metabolites, (Ahuja et al. 2012; Bednarek 2012) and several defense-related proteins such as chitinases, glucanases, lectins, thionins, and defensins (Carvalho and Gomes 2009).

Defensins, which are pathogenesis-related proteins produced by plants, invertebrate and vertebrate animals, are basic, small (around 50 amino acids, about $5 \mathrm{kDa}$ ), cysteine-rich-peptides whose three-dimensional structure presents one $\alpha$-helix and three antiparallel $\beta$-sheets stabilized by an $\alpha \beta$ motif (Lay and Anderson 2005; Carvalho and Gomes 2009). Defensins have a broad range of biological activity, including inhibition of $\alpha$-amylases (Bloch and Richardson 1991; Pelegrini et al. 2008) and proteases (Wijaya et al. 2000; Melo et al. 2002), antimicrobial activity (Ye and Ng 2001; Wong and Ng 2005; de Zélicourt et al. 2007), inhibition of protein synthesis (Mendez et al. 1990, 1996), blockage of ionic channels (Spelbrink et al. 2004) and interference in cell cycle by DNA binding (Lobo et al. 2007).

Transgenic plants expressing defensins have been shown to be an alternative strategy to protect plants against pathogens (De Bondt et al. 1999; Gao et al. 2000; Parashina et al. 2000; Chen et al. 2002, 2006; Park et al. 2002; Chan et al. 2005; Zhu et al. 2007; Anuradha et al. 2008; Choy et al. 2009; Kovalskaya and Hammond 2009; Abdallah et al. 2010; Jha and Chattoo 2010) specially in case there is no source of natural resistance for breeding programs.

The pea (Pisum sativum) defensin Drr230a, transgenically expressed in tobacco, has been previously shown to present antimicrobial activity against the entomopathogenic fungus Trichoderma reesei and against the phytopathogenic fungi $F$. solani, $F$. oxysporum, Ascochyta pisi, A. pinodes, A. lentis, Alternaria alternata, and Leptosphaeria maculans (Lai et al. 2002).

Considering the potential of Drr230a to control other relevant fungal diseases in agriculture, in the present study, we describe the expression of the drr230a gene in Pichia pastoris, the purification of the resulting recombinant Drr230a (rDrr230a) and evaluations of its activity against the impacting cotton and soybean fungi $C$. gossypii var. cephalosporioides, $P$. pachyrhizi and F. tucumaniae.

\section{Materials and methods}

\section{Phytopathogenic fungi}

The fungal pathogen $F$. solani (Mart.) Sacc. f. sp. glycines (=F. tucumaniae), which causes soybean sudden death syndrome, was provided by Dr. Leila Costamilan (Embrapa Trigo, Passo Fundo-RS, Brazil). C. gossypii (South) var. cephalosporioides A. S. Costa, a fungal pathogen that causes cotton ramulosis, was provided by Dr. Nelson Dias Suassuna (Embrapa Algodão, Campina Grande-PB, Brazil). Both fungi were maintained by in vitro cultivation and spore lyophilization.

The P. pachyrhizi H. \& P. Syd. uredospores, which cause Asian soybean rust, were collected at soybean fields in Londrina-PR, Brazil and maintained in soybean plants under greenhouse controlled conditions at Embrapa Soja, Londrina-PR, Brazil.

\section{Subcloning of $d r r 230 a$ gene into yeast expression vector}

The drr230a defensin gene (Genebank accession AF525685), provided by Dr. Richard Fobert (National Research Council Canada, Plant Biotechnology Institute), was originally isolated from pea ( $P$. sativum) and previously demonstrated to present antifungal activity (Lai et al. 2002). The $d r r 230 a$ gene, initially subcloned into a plant transformation vector, provided by Dr Richard Fobert, was amplified by using the primers DRR230a01For ( $5^{\prime}$ GCC GAA TTC AAC ACA TGT GAG AAC $3^{\prime}$ ) and DRR230a02Rev (5' TGG GCG GCC GCT CAA TGA TGA TGA TGA TGA TGG CAG TTT TTA GTA CAC CAA CAG CGA AAG TCA TC $3^{\prime}$ ) designed to insert EcoRI and NotI restriction sites at the $5^{\prime}$ and $3^{\prime}$ ends, respectively, to subclone into the $P$. pastoris expression vector $\mathrm{pPICZ} \alpha \mathrm{A}^{\circledR}$ (Invitrogen Co.). Moreover, by using the reverse primer DRR230a02Rev a coding sequence of six histidines (6xHis) was added to the $3^{\prime}$ end of the $d r r 230 a$ gene, to enable purification of the corresponding recombinant rDrr230a protein by immobilized metal affinity chromatography (IMAC) and immunodetection with commercial anti-His antibodies. The amplicon comprising the $d r r 230 a$ gene with 6xHis-tag was subcloned into the EcoRI and NotI sites of pPICZ $\alpha A^{\circledR}$ in frame with the $\alpha$-factor secretion peptide signal, downstream of the alcohol oxidase I promoter.

The resulting construct pPICZ $\alpha A-D r r 230 a$ integrity was confirmed by automated ABI sequencing (Perkim-Elmer). The pPICZ $\alpha$ A-Drr230a construct was used to transform $P$. pastoris competent cells strain X-33 by using $20 \mu \mathrm{g}$ of SacI linearized DNA via electroporation (in accordance with the manufacturer). Clones were selected on YPD broth (1\% 
yeast extract; $2 \%$ dextrose; $2 \%$ peptone, $2 \%$ agar) plates containing zeocin $(100 \mu \mathrm{g} / \mathrm{ml})$ and by PCR analyses. Clones were then cultivated in plates with higher zeocin concentration $(500 \mu \mathrm{g} / \mathrm{ml})$ to increase chances of selecting those with two gene copies in the yeast genome (Vassileva and Chugh 2001).

\section{Expression of rDrr230a in $P$. pastoris and its purification by immobilized metal affinity chromatography (IMAC)}

One positive clone containing the pPICZ $\alpha A-D r r 230 \mathrm{a}$ construct was inoculated in $2 \mathrm{ml}$ of YPD broth $(1 \%$ yeast extract; $2 \%$ dextrose; $2 \%$ peptone) and incubated over night at $28{ }^{\circ} \mathrm{C}$ and $200 \mathrm{rpm}$ (i.e. pre-inoculum). Afterwards, the $2 \mathrm{ml}$ pre-inoculum was diluted in $200 \mathrm{ml}$ of BMG broth (1.34 \% de YNB, $1 \%$ de glycerol, $4 \times 10^{-5} \%$ Biotin, $100 \mathrm{mM}$ potassium phosphate buffer, $\mathrm{pH}$ 6.0) and incubated for $24 \mathrm{~h}$ to reach $\mathrm{OD}_{600}=20$ (i.e. inoculum). Then, those $200 \mathrm{ml}$ inoculum were centrifuged $\left(1500 \times g ; 25^{\circ} \mathrm{C}\right.$; $5 \mathrm{~min}$ ) and the resulting pellet was resuspended in the same volume of BMM broth $(1.34 \%$ de YNB, $1 \%$ methanol, $4 \times 10^{-5} \%$ Biotin, $100 \mathrm{mM}$ potassium phosphate buffer, $\mathrm{pH}$ 6.0) to induce expression of the recombinant protein rDrr230a. During the induced expression, the culture was incubated at $28{ }^{\circ} \mathrm{C}$ and $220 \mathrm{rpm}$ agitation for 4 days. Aliquots of the culture supernatant were analyzed by SDSTRICINE-PAGE $14 \%$ and Western Blot probed with commercial anti-His antibodies (Invitrogen Co.) to detect the His-tag rDrr230a protein (Towbin et al. 1979; Schagger and Von Jagow 1987).

Supernatant from the expression culture was filtered through $0.2 \mu \mathrm{m}$ membranes (Millex-GV, Millipore), diluted in binding buffer (100 $\mathrm{mM}$ sodium phosphate buffer, $\mathrm{pH}$ 7.4; $500 \mathrm{mM} \mathrm{NaCl}$ ) and applied into a His-Trap FF crude column $(1.6 \times 2.5 \mathrm{~cm} ; 5 \mathrm{ml})$ (GE Helthcare) previously equilibrated with binding buffer $\mathrm{pH} 7.4$ at $5 \mathrm{ml} / \mathrm{min}$. Binding recombinant rDrr230a protein was eluted with elution buffer (binding buffer containing imidazole to final concentration of $500 \mathrm{mM}$ ) and checked for purity by SDSTRICINE-PAGE $14 \%$ and Western Blot probed with commercial anti-His antibodies (Invitrogen Co.). The fraction containing the recombinant rDrr230a protein was dialyzed, lyophilized and dissolved in deionized water. The $\mathrm{N}$-terminal amino acid sequence of rDrr230a was confirmed by sequencing using Edman's degradation technique.

\section{Antifungal bioassay against non-biotrophic phytopathogenic fungi}

Bioassays against the soybean pathogenic fungus $F$. tucumaniae and against the cotton pathogenic fungus $C$. gossypii var. cephalosporioides were performed in two quantitative assays. The first assay, performed to analyze inhibition of fungal growth, consisted of incubating $10 \mu \mathrm{l}$ of a solution containing $10^{4}$ spores $/ \mathrm{ml}$ with $80 \mu \mathrm{l}$ of liquid PDB (Potato Dextrose Broth) and rDrr230a to different final concentrations, varying from 0.2 up to $60 \mathrm{ng} / \mu \mathrm{l}$ in the case of inhibition of $F$. tucumaniae growth, and varying from 5 up to $50 \mathrm{ng} / \mu \mathrm{l}$ in the case of inhibition of C. gossypii var. cephalosporioides growth (assay total volume corresponded to $100 \mu \mathrm{l}$ per sample). The assay was done in a 96-well microplate and the samples were incubated at $28^{\circ} \mathrm{C}$ for $48 \mathrm{~h}$ in the dark. The inhibition of fungal growth was measured by optical density in a microplate reader (BIORAD) at $600 \mathrm{~nm}$. All treatments were done in triplicates. Distilled water and hydrogen peroxide $(70 \mu \mathrm{M})$ were used as negative and positive controls, respectively.

The second assay, performed to analyze inhibition of spore germination, was carried out using $5 \mu \mathrm{l}$ of a solution containing $10^{4}$ spores $/ \mathrm{ml}$ and $15 \mu \mathrm{l}$ of a solution containing rDrr230a. The samples were incubated at $28{ }^{\circ} \mathrm{C}$ for $12 \mathrm{~h}$. The germinated spores were counted in a Neubauer chamber upon observation under an optical microscope (Olympus Optical Co.) within several fields of 100 spores/field. Moreover, representative sample fields were photographed with the same equipment. All treatments were done in triplicates. Distilled water and hydrogen peroxide $(70 \mu \mathrm{M})$ were used as negative and positive controls, respectively.

\section{Antifungal bioassay against obligatory biotrophic phytopathogenic fungus}

Bioassays against the obligatory biotrophic soybean pathogenic fungus $P$. pachyrhizi were performed in two assays. The first assay was performed to analyze the disease severity caused in planta by $P$. pachyrhizi in presence or absence of rDrr230a. This assay was carried out by inoculating half soybean detached leaflets with $150 \mu \mathrm{l}$ of a solution containing $8 \times 10^{4}$ uredospores $/ \mathrm{ml}$ (in sterile distilled water containing $0.01 \%$ v/v Tween 20), by brushing. Fourteen minutes afterwards, the same half leaflets were treated, by brushing, with rDrr230a to final concentration $3 \mu \mathrm{g} / \mu \mathrm{l}$. The leaflets were then incubated at $24{ }^{\circ} \mathrm{C}$ for 14 days in a humid chamber. The severity was evaluated daily. All treatments were done in triplicates. Distilled water was used as the negative control. In addition, $24 \mathrm{~h}$ post inoculation, one half leaflet of each treatment was punched with a microtube cap to collect samples for microscopy analyses of uresdospore germination under a Scanning Electron Microscope. For this reason, each collected leaf disk was immediately fixed in glutaraldehyde/paraformaldehyde solution. Afterwards, the leaf disks were further fixed in osmium tetroxide and then in uranyl acetate. Dehydration of the leaf disks was performed in 
acetone solutions of serially increasing concentrations. Acetone was removed from the leaf disk samples by critical point drying. Finally, the leaf disks were coated with gold by low-vacuum sputter coating, then observed and photographed under Scanning Electron Microscope (Jeol).

The second assay, performed to analyze inhibition of uredospore germination, was carried out by using $50 \mu \mathrm{l}$ of a solution containing $10^{4}$ uredospores $/ \mathrm{ml}$ (in sterile distilled water containing $0.01 \% \mathrm{v} / \mathrm{v}$ Tween 20 ) and rDrr230a at final concentration of $3 \mu \mathrm{g} / \mu \mathrm{l}$, in a final volume of $100 \mu \mathrm{l}$. The assay was done in a 96-well microplate and the samples were incubated at $24{ }^{\circ} \mathrm{C}$ in a humid chamber overnight. To end up the assay, lactophenol was added. The germinated uredospores were counted in a Neubauer chamber upon observation with an optical microscope (Olympus Optical Co) within several fields of 100 uredospores/field. Moreover, representative sample fields were photographed with the same equipment. All assays were done in triplicates. Distilled water was used as negative control of inhibition of uredospore germination.

\section{Results and discussion}

\section{Expression of rDrr230a in $P$. pastoris and its purification by immobilized metal affinity chromatography (IMAC)}

To evaluate the biological activity of rDrr230a against phytopathogenic fungi, the corresponding gene was introduced into the $P$. pastoris expression vector pPICZ $\alpha \mathrm{A}$ and the rDrr230a protein was expressed under control of the pAOX1 methanol-inducible promoter (Fig. 1). The resulting recombinant protein $\mathrm{rDr} 230 \mathrm{a}$ was secreted due to the $\alpha$-mating factor signal peptide present in the vector (Fig. 1). A poly-histidine tag (6xHis) was added to the $3^{\prime}$ end of the gene sequence to enable purification of the resulting recombinant His-tagged protein (Fig. 1) through IMAC. $P$. pastoris strain X-33 was transformed with the expression construct and resulting colonies were assayed in plates with high concentration of the selection agent zeocin. Zeocin resistant clones were used in a small-scale expression assay. The clone that presented the highest expression level was chosen to proceed to large-scale production of rDrr230a.

The recombinant protein $\mathrm{rDrr} 230 \mathrm{a}$ was expressed upon promoter induction with methanol, and untransformed cells were used as negative control sample. Aliquots from the expression set up were collected every $24 \mathrm{~h}$ in a time course from $24 \mathrm{~h}$ up to $96 \mathrm{~h}$, and analyzed in TRICINESDS-PAGE. The production of rDrr230a occurred at $24 \mathrm{~h}$, remaining until $96 \mathrm{~h}$, and $\mathrm{rDrr} 230 \mathrm{a}$ presented the expected molecular size of $6.52 \mathrm{kDa}$ (Fig. 2a, b).
The supernatant, containing the secreted rDrr230a, was directly submitted to purification by IMAC. The eluted fractions were analyzed by TRICINE-SDS-PAGE $14 \%$ and Western blot probed with anti-His antibody, confirming the expression of a recombinant protein comprising 6.52 $\mathrm{KDa}$ (Fig. 3a, b). The N-terminal amino acid sequence of rDrr230a was confirmed by Edman's degradation sequencing, which revealed additional amino acids corresponding to leftovers of the Kex 2 cleavage site (EAEA) and EcoRI site (EF) at the N-terminus (Fig. 1). Considering as well the prediction of amino acid sequence based on nucleotide sequence, the resulting protein sequence of the His-tagged recombinant rDrr230a (57 residues) is EAEA EF NTC ENL AGS YKG VCF GGC DRH CRT QEG AIS GRC RDD FRC WCT KNC HHHHHH, as shown in Fig. 1. Quantification of purified rDrr230a, done by 2D-Quant method (Amersham), indicated a recombinant protein recovery estimated in $3.5 \mathrm{mg} / \mathrm{l}$.

\section{rDrr230a activity against non-biotrophic and obligatory biotrophic phytopathogenic fungi}

To analyze inhibition of fungal growth upon incubation with the defensin, spores of the non-biotrophic fungi $F$. tucumaniae and C. gossypii var. cephalosporioides were incubated with rDrr230a in microplate wells in liquid medium for $48 \mathrm{~h}$. This bioassay was performed by using a concentration range of rDrr230a varying from $0.2 \mathrm{ng} / \mu \mathrm{l}$ up to $60 \mathrm{ng} / \mu \mathrm{l}(0.03 \mu \mathrm{M}$ up to $9.20 \mu \mathrm{M})$ to analyze inhibition of $F$. tucumaniae growth and a range varying from 5 up to $50 \mathrm{ng} / \mu \mathrm{l}(0.77 \mu \mathrm{M}$ up to $7.67 \mu \mathrm{M})$ in the case of $C$. gossypii var. cephalosporioides (Fig. 4). Based on the resulting curves of inhibition of fungal growth of both fungi upon incubation with $\mathrm{rDrr} 230 \mathrm{a}$, the calculated $\mathrm{IC}_{50}$ against F. tucumaniae was $7.67 \mu \mathrm{M}(50 \mathrm{ng} / \mu \mathrm{l}$; Fig. $4 \mathrm{a})$ and against C. gossypii var. cephalosporioides corresponded to $0.84 \mu \mathrm{M}(5.5 \mathrm{ng} / \mu \mathrm{l}$; Fig. $4 \mathrm{~b})$, indicating that $\mathrm{rDrr} 230 \mathrm{a}$ is moderately efficient against $F$. tucumaniae and highly potent against $C$. gossypii var. cephalosporioides.

To further investigate the deleterious effect of rDrr230a upon both fungi, the activity of rDrr230a against spore germination of $F$. tucumaniae and $C$. gossypii var. cephalosporioides was tested at $25 \mathrm{ng} / \mu \mathrm{l}(3.83 \mu \mathrm{M}) 12 \mathrm{~h}$ post incubation, in a similar microplate setup as previously described. At concentration $25 \mathrm{ng} / \mu \mathrm{l}(3.83 \mu \mathrm{M})$ the spore germination of both $F$. tucumaniae and $C$. gossypii var. cephalosporioides was inhibited in $100 \%$ (Fig. 5a, c, e) despite the fact that the spores of both fungi germinated normally under incubation in water (Fig. 5a, b, d). These observations demonstrate that rDrr230a affects the fungal development of $F$. tucumaniae and $C$. gossypii var. cephalosporioides from the very beginning, i.e. since the spore germination. 


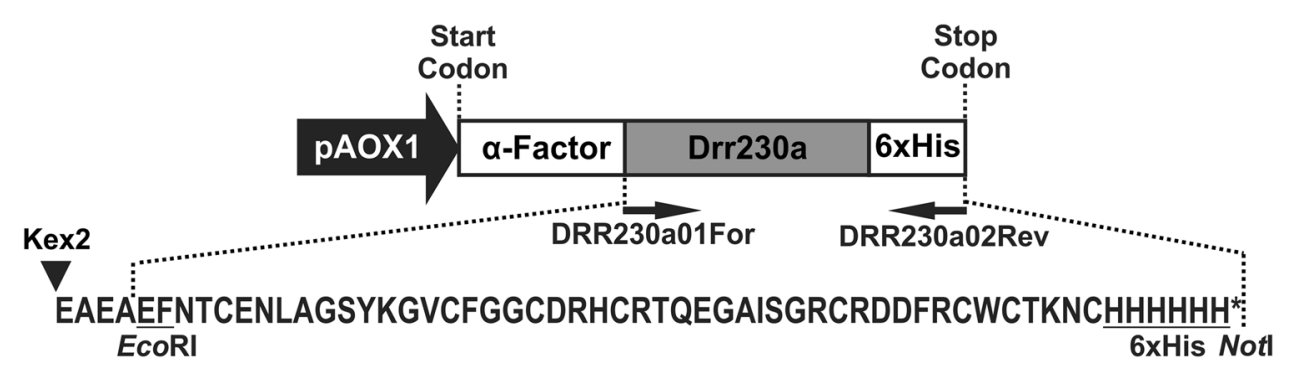

Fig. 1 Schematic description of the expression cassette construct designed to express Histidine-tagged recombinant Drr230a in yeast ( $P$. pastoris). The drr230a gene was subcloned into the yeast expression vector pPICZ $\alpha \mathrm{A}$ (Invitrogen Co.) under the control of the alcohol oxidase 1 promoter (pAOX1) inducible by methanol. The orientations of the primers DRR230a01For and DRR230a02Rev, including the respective restriction $E c o$ RI (resulting in addition of $E F$ residues at the recombinant protein $\mathrm{N}$-terminus) and NotI cloning sites (not expressed), are indicated by arrows. The recombinant

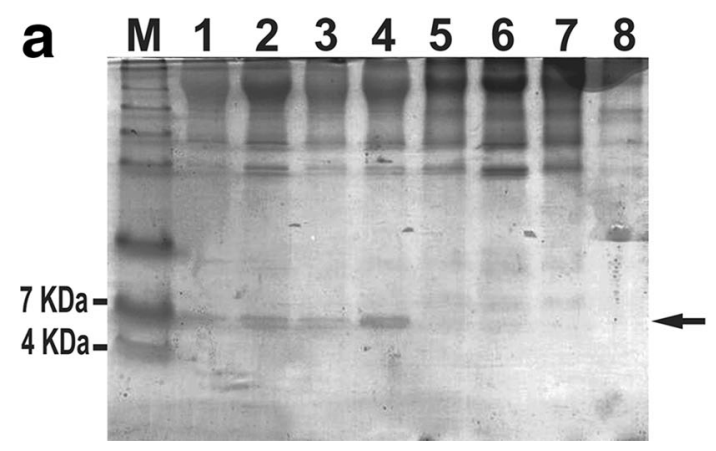

Fig. 2 Expression of rDrr230a in $P$. pastoris X-33 cells. a SDSTRICINE-PAGE analysis of the expression of the His-tagged rDrr230a protein from 24 to $96 \mathrm{~h}$ after methanol-induction. b Western blot analysis of expressed His-tagged rDrr230a protein probed with anti-His antibody (Invitrogen). Molecular mass marker See Blue ${ }^{\circledR}$ Plus 2 Prestained Standard, Invitrogen (lane $\mathrm{M}$ ).

The $P$. pastoris system was suitable to produce active rDrr230a (Figs. 2, 3) as shown by biological activity of the resulting recombinant protein against $F$. tucumaniae and $C$. gossypii var. cephalosporioides (Fig. 4). There are several other reports corroborating that yeast expression systems are adequate to produce active antimicrobial peptides rich in sulfide-bridges, such as defensins. For instance, $P$. pastoris yeast expression systems were successfully used to produce active plant defensins such as the corn defensin PDC1 (Kant et al. 2009), the dimeric defensin SPE10 (Song et al. 2005), the pea defensin Psd1 (Almeida et al. 2001), the sugar beet defensin AX2 (Kristensen et al. 1999), the mungbean defensin VrD1 (Jrchen et al. 2004) and the wild tobacco defensin NmDef02 (Portieles et al. 2010).

Besides expression of plant defensins in yeast systems, there are reports as well of expression of plant defensins in bacteria, in all cases resulting in production of bioactive peptides against various fungi, such as the wild indigo protein (sequence depicted above) is expressed in frame with the Saccharomyces cerevisiae secretion mating $\alpha$-factor signal peptide $(\alpha$-Factor), which is cleaved before protein export at the Kex 2 signal cleavage site (Kex2), resulting in the addition of four residues (EAEA) at the N-terminal end of the recombinant protein. A Histidine tag (6xHis; $H H H H H H)$, followed by a stop codon (asterisk) was included at the $\mathrm{C}$-terminal end of the sequence to facilitate recombinant protein purification by Immobilized metal affinity chromatography

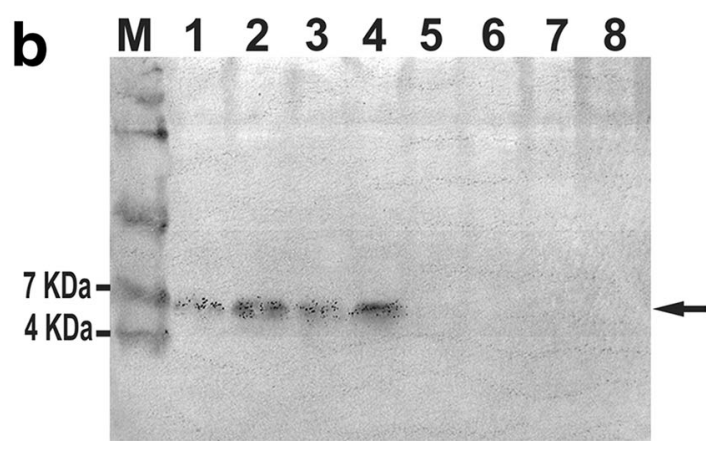

Supernatant from $P$. pastoris X-33 culture expressing rDrr230a $24 \mathrm{~h}$ (lane 1), $48 \mathrm{~h}$ (lane 2), $72 \mathrm{~h}$ (lane 3) and $96 \mathrm{~h}$ (lane 4) post-induction. Supernatant from $P$. pastoris X-33 untransformed culture $24 \mathrm{~h}$ (lane 5), $48 \mathrm{~h}$ (lane 6), $72 \mathrm{~h}$ (lane 7) and $96 \mathrm{~h}$ (lane 8) post-induction. Arrows indicate bands corresponding to the expressed rDrr230a $(6.52 \mathrm{kDa})$

defensin TvD1 (Vijayan et al. 2008), the pepper defensin J1-1 (Seo et al. 2014) and the corn defensin PDC1 (Kant et al. 2009). Nevertheless, when expressed in E. coli as compared to the P. pastoris system, PDC1 expressed in yeast was more efficient to inhibit growth of $F$. graminearum than the same protein expressed in bacteria (Kant et al. 2009), as it is expected, since yeast is an eukaryotic system, what favors correct cysteine-bond formation, protein correct folding and consequently protein full activity (Demain and Vaishnav 2009; Fickers 2014).

Concerning recombinant plant defensins tested against phytopathogenic fungi from the Colletotrichum genus, Seo et al. (2014) demonstrated activity of the defensin J1-1, expressed in bacteria, against $C$. gloeosporioides $\left(\mathrm{IC}_{50}\right.$ $8.3 \mu \mathrm{M})$. The defensin SPE10, expressed in yeast, also presented antifungal activity when tested towards the same fungal species (Song et al. 2005), i.e. C. gloeosporioides, despite being less potent than J1-1 $\left(\mathrm{IC}_{50}>20 \mu \mathrm{M}\right)$. 


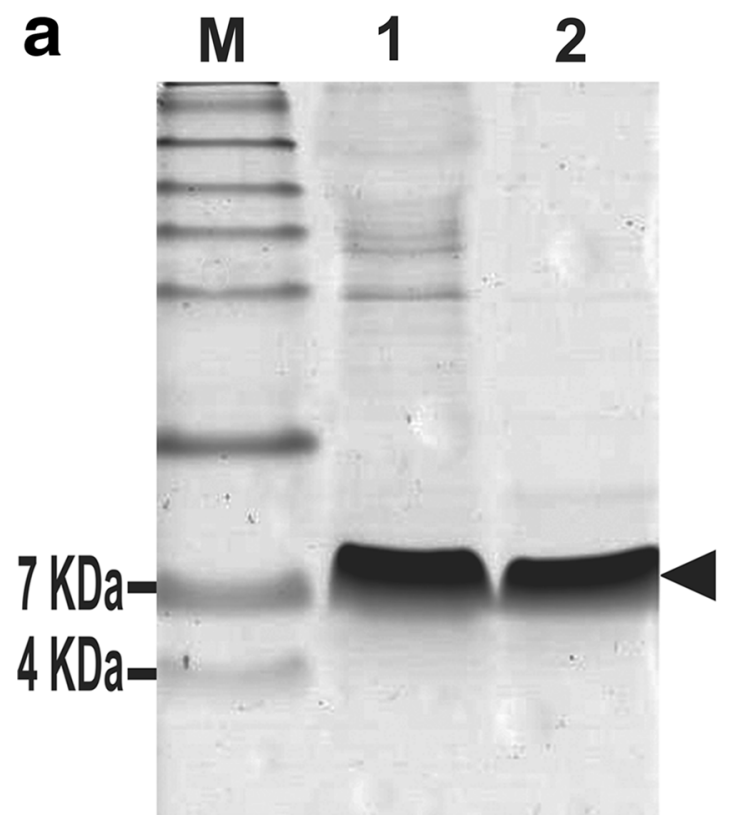

Fig. 3 Purification of rDrr230a expressed in P. pastoris X-33 cells. rDrr230a was purified by immobilized-metal affinity chromatography (IMAC). a SDS-TRICINE-PAGE analysis of the purification of rDrr230a. b Western blot analysis of purification of rDrr230a, probed with anti-His antibody (Invitrogen). Molecular mass marker See Blue ${ }^{\circledR}$ Plus 2 Prestained Standard, Invitrogen (lane $M$ ). Supernatant

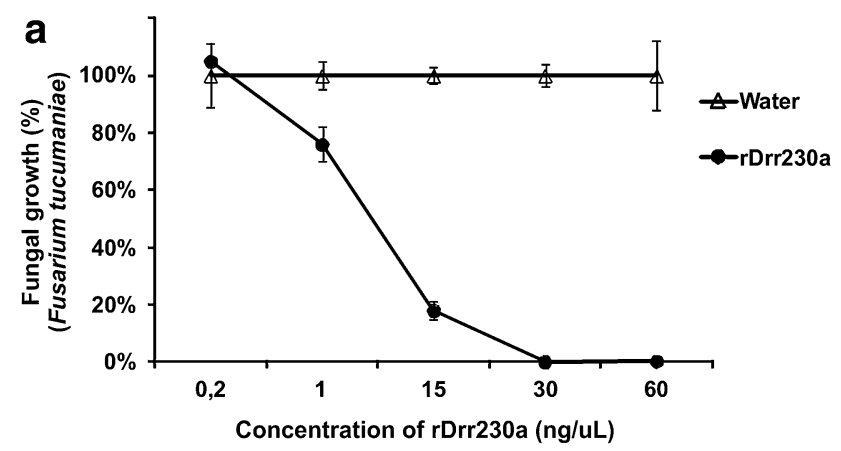

Fig. 4 Inhibition of fungal growth of the non-biotrophic phytopathogenic fungi $F$. tucumaniae and $C$. gossypii var. cephalosporioides by $\mathrm{rDrr} 230 \mathrm{a}$. Bioassays were performed in microplate wells in liquid medium for $48 \mathrm{~h}$. The data are mean \pm standard deviation $(n=3)$. a Curve of inhibition of $F$. tucumaniae growth upon incubation with rDrr230a in a concentration range varying from

Interestingly, rDrr230a is considerably more potent than J1-1 and SPE10 against a target fungus from the Colletotrichum genus (C. gossypii var. cephalosporioides) $\left(\mathrm{IC}_{50} 0.84 \mu \mathrm{M}\right)$, what represents around tenfold increase in antifungal potency. This implies that the recombinant rDrr230a expressed in yeast was correctly folded and therefore was biologically active.

In what concerns activity against the Fusarium genus, rDrr230a $\left(\mathrm{IC}_{50} 7.67 \mu \mathrm{M}\right)$ was shown to be more effective than the defensin PDC1 produced in bacteria $\left(\mathrm{IC}_{50} 30 \mu \mathrm{M}\right)$,

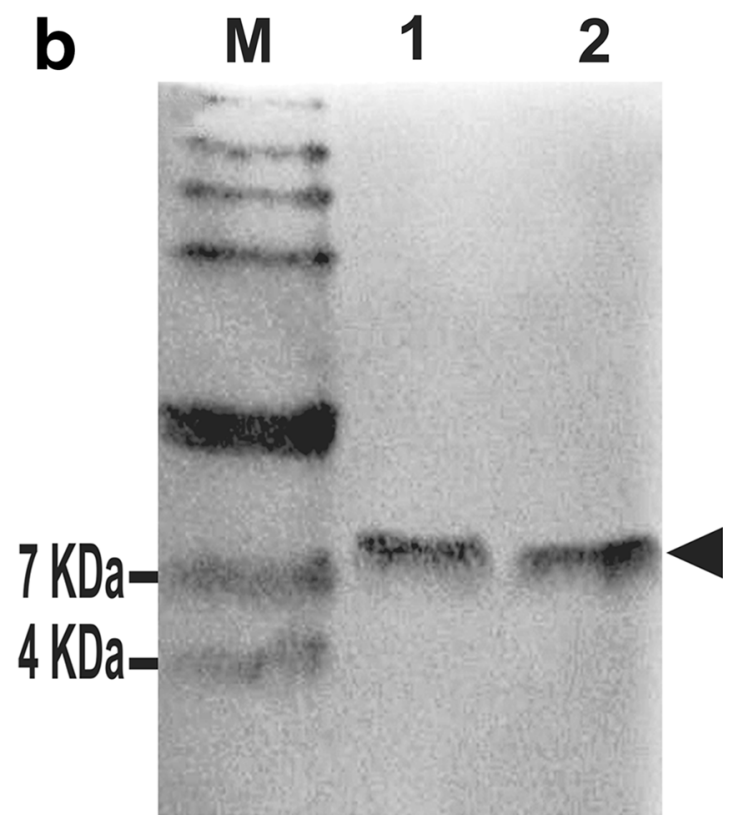

from $P$. pastoris X-33 culture expressing rDrr230a $96 \mathrm{~h}$ after methanol-induction (lane 1). Eluate fraction from IMAC, corresponding to $P$. pastoris-expressed rDrr230a $96 \mathrm{~h}$ after methanol-induction (lane 2). Arrows indicate bands corresponding to the purified rDrr230a $(6.52 \mathrm{kDa})$

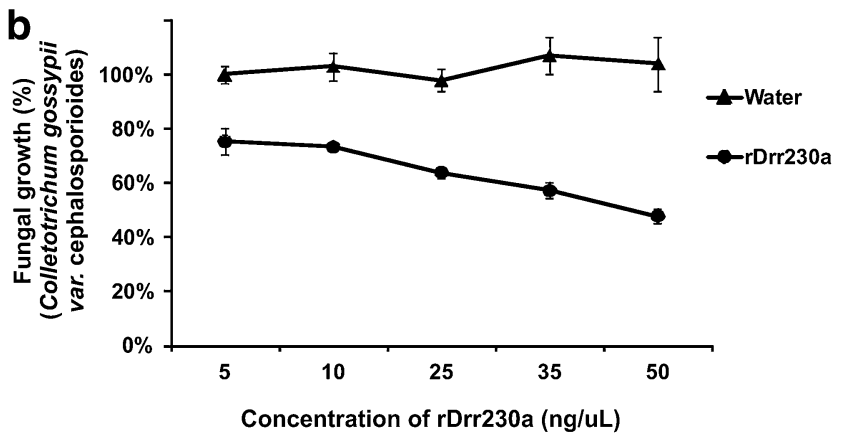

$0.2 \mathrm{ng} / \mu \mathrm{l}$ up to $60 \mathrm{ng} / \mu \mathrm{l}(0.03 \mu \mathrm{M}$ up to $9.20 \mu \mathrm{M})$. Calculated $\mathrm{IC}_{50}$ against $F$. tucumaniae corresponds to $7.67 \mu \mathrm{M}(50 \mathrm{ng} / \mu \mathrm{l})$. b Curve of inhibition of $C$. gossypii var. cephalosporioides growth upon incubation with rDrr230a in a concentration range varying from 5 up to $50 \mathrm{ng} / \mu \mathrm{l}(0.77 \mu \mathrm{M}$ up to $7.67 \mu \mathrm{M})$. Calculated $\mathrm{IC}_{50}$ against $C$. gossypii var. cephalosporioides corresponds to $0.84 \mu \mathrm{M}(5.5 \mathrm{ng} / \mu \mathrm{l})$

though being as effective as the same recombinant defensin expressed in yeast $\left(\mathrm{IC}_{50} 7.5 \mu \mathrm{M}\right.$; Kant et al. 2009). Moreover, rDrr230a $\left(\mathrm{IC}_{50} 7.67 \mu \mathrm{M}\right)$ was more effective than the defensin SPE10 $\left(\mathrm{IC}_{50}>20 \mu \mathrm{M}\right)$, but less effective than the recombinant defensins $\mathrm{VrD1}$ ( $\mathrm{IC}_{50} 1.0$ up to $3.4 \mu \mathrm{M}$ against different $F$. oxysporum isolates), NmDef02 ( $\mathrm{IC}_{50} 1.0 \mu \mathrm{M}$ against $F$. oxysporum) and TvD1 ( $\mathrm{IC}_{50}<5.0 \mu \mathrm{M}$ against both $F$. oxysporum and $F$. moniliforme) against Fusarium species (Jrchen et al. 2004; Song et al. 2005; Vijayan et al. 2008; Portieles et al. 2010). 


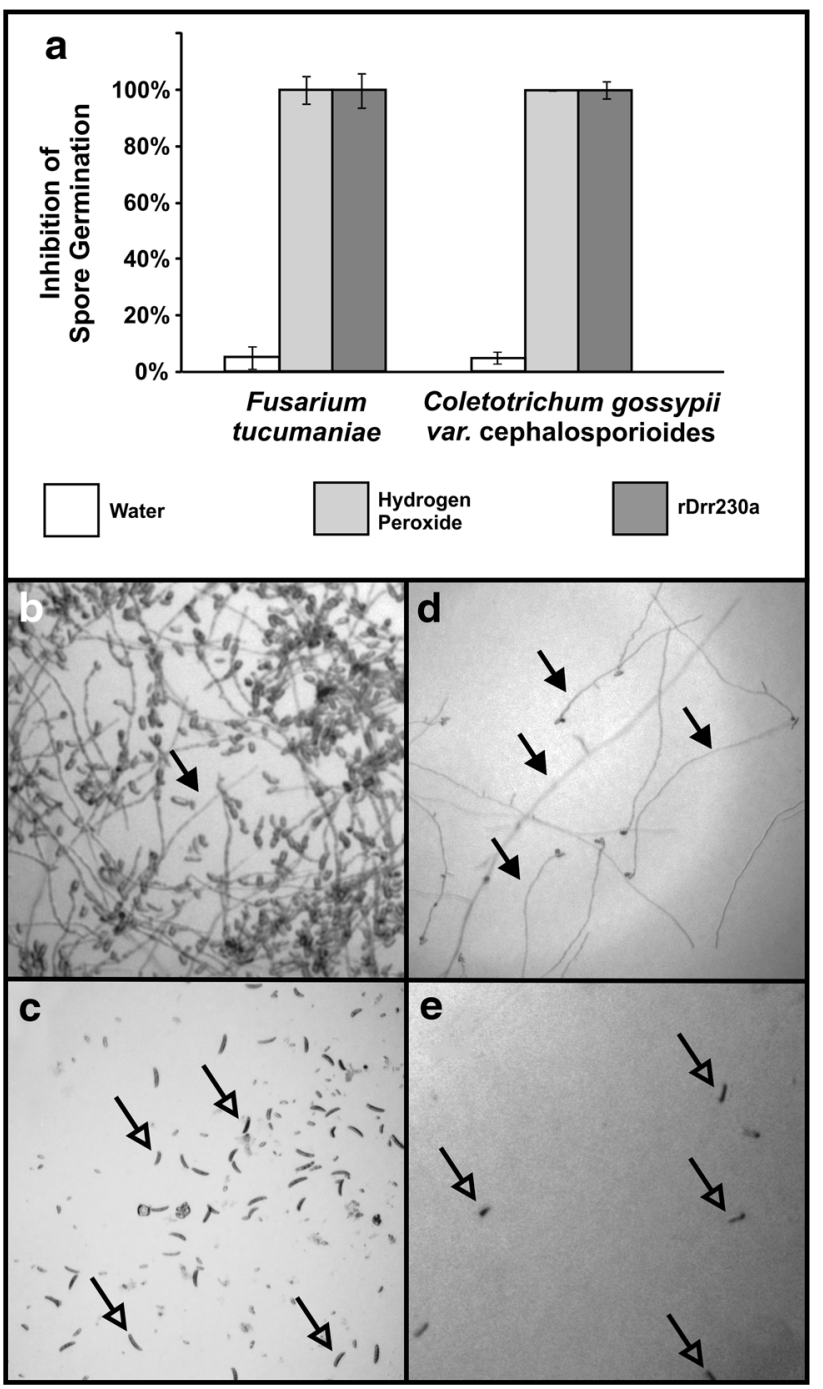

Fig. 5 Inhibition of spore germination of the non-biotrophic phytopathogenic fungi $F$. tucumaniae and C. gossypii var. cephalosporioides by $\mathrm{rDr} 230 \mathrm{a}$. Bioassays were performed in microplate wells in liquid medium for $12 \mathrm{~h}$. a Percentage of the inhibition of spore germination of $F$. tucumaniae and $C$. gossypii var. cephalosporioides upon incubation with rDrr230a. Fungal spores were incubated either with $\mathrm{rDr} 230 \mathrm{a}$ at $25 \mathrm{ng} / \mu \mathrm{l}$, water or hydrogen peroxide at $70 \mu \mathrm{M}$. The data in a are mean \pm standard deviation $(n=3)$. b Representative image of $F$. tucumaniae germinating spores (closed arrows) under water incubation. c Representative image of $F$. tucumaniae nongerminating spores (open arrows) under rDrr230a incubation. d Representative image of $C$. gossypii var. cephalosporioides germinating spores (closed arrows) under water incubation. e Representative image of $C$. gossypii var. cephalosporioides non-germinating spores (open arrows) under rDrr230a incubation

As $P$. pachyrhizi is an obligatory biotrophic phytopathogenic fungus, it is not feasible to assess rDrr230a in vitro activity against its growth. Therefore, the impact of rDrr230a upon $P$. pachyrhizi infection was assessed by in planta bioassays. For that reason, soybean detached leaflets were inoculated with $P$. pachyrhizi uredospores either in presence or absence of rDrr230a and the disease severity was evaluated daily for 2 weeks, by using a scale varying from $0 \%$ up to $100 \%$ severity (Godoy et al. 2006). rDrr230a at $3 \mu \mathrm{g} / \mu \mathrm{l}(460.12 \mu \mathrm{M})$ resulted in no disease, i.e. $0 \%$ severity, as compared to average $80 \%$ rust severity in the absence of the recombinant protein, 14 days post inoculation (Fig. 6a, c). A leaf disk sample of each treatment was fixed at 1 day post inoculation for scanning electron microscopy analyses. The corresponding micrographs depict representative images of no uredospore germination onto well preserved plant epidermal cells when rDrr230a is present, whereas there is normal uredospore germination onto damaged epidermal plant cells in absence of rDrr230a (Fig. 5b, d). Moreover, inhibition of $P$. pachyrhizi uredospore germination was evaluated in vitro, under similar setup as previously evaluated for F. tucumaniae and C. gossypii var. cephalosporioides. In this case, rDrr230a inhibited $100 \%$ spore germination of $P$. pachyrhizi at $3 \mu \mathrm{g} / \mu \mathrm{l}(460.12 \mu \mathrm{M})$ (Fig. 7). Despite the considerably high concentration used that inhibited in vitro $P$. pachyrhizi spore germination and decreased in plant disease severity, to our knowledge, this is the first report of a plant defensin being active against a obligatory biotrophic phytopathogenic fungus.

The antifungal effect of wild type Drr230a protein (also named as DRR206) was firstly reported by Wang and Nowak (1999) who showed that transgenic canola (Brassica napus)

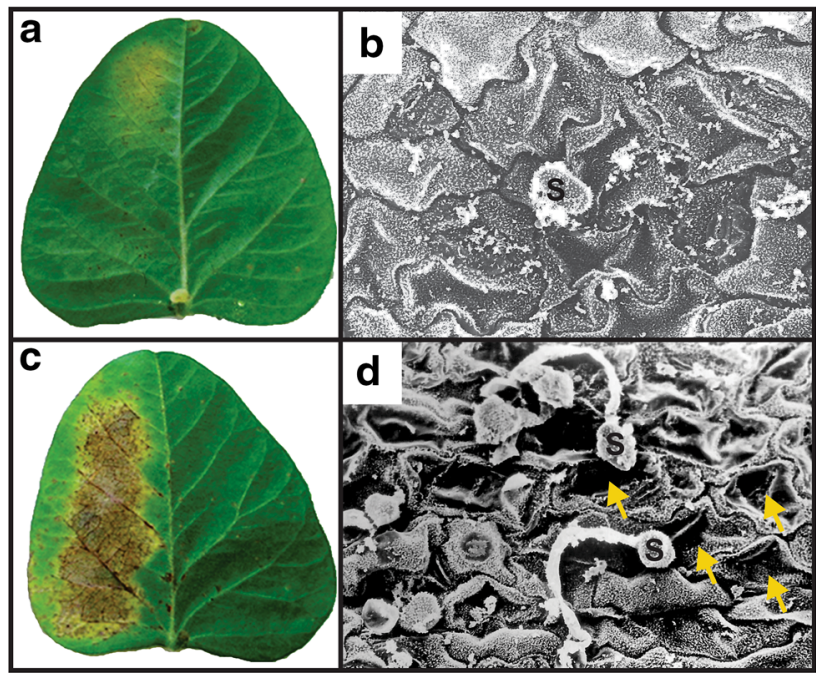

Fig. 6 Plant disease severity (Asian soybean rust) caused by the obligatory biotrophic phytopathogenic fungus $P$. pachyrhizi upon incubation with rDrr230a. a, c Representative half detached soybean leaflets inoculated with $P$. pachyrhizi uredospores either in presence rDrr230a at $3 \mu \mathrm{g} / \mu \mathrm{l}$ (a) or absence of rDrr230a (c) 14 days post inoculation. b, d Sampled areas from inoculated detached leaflets fixed at 1 day post inoculation and analyzed by scanning electron microscopy. Representative micrographs depict no uredospore (S) germination onto well preserved plant epidermal cells when rDrr230a is present (b), whereas there is normal uredospore (S) germination onto damaged epidermal plant cells (yellow arrows) in absence of rDrr230a (d) 


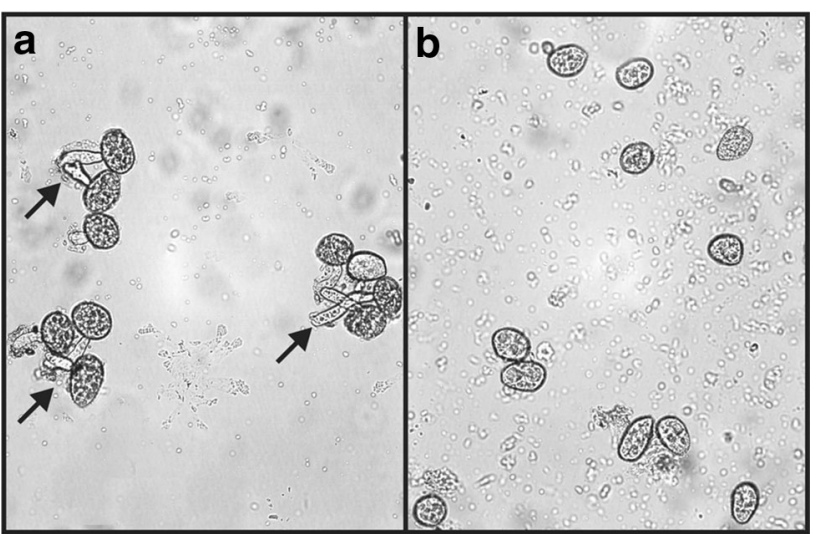

Fig. 7 Inhibition of spore germination of the obligatory biotrophic phytopathogenic fungus $P$. pachyrhizi by rDrr230a. Bioassays were performed in microplate wells in liquid medium for $12 \mathrm{~h}$. a Representative image of $P$. pachyrhizi germinating spores (arrows) under water incubation. b Representative image of $P$. pachyrhizi nongerminating spores under incubation with $\mathrm{rDrr} 230 \mathrm{a}$ at $3 \mu \mathrm{g} / \mu \mathrm{l}$

expressing Drr230a was active against the fungus L. maculans, which causes blackleg disease on Brassica crops. Wang and Fristensky 2001 additionally demonstrated that Drr230a expressed in transgenic canola was effective against the phytopathogenic fungi Rhizoctonia solani (soil-borne pathogen that causes various plant diseases in a wide host range such as collar rot, root rot, damping off and wire stem) and Sclerotinia sclerotiorum (that causes white mold in a wide host range of plants).

In 2002 Lai and cols showed that leaf extracts from transgenic tobacco plants expressing Drr230a were active against the entomopathogenic fungus $T$. reesei and the phytopathogenic fungi $F$. solani, $F$. oxysporum (both Fusarium species that cause various diseases in plants and have extremely broad host range), A. pisi, A. pinodes, A. lentis (all Ascochyta species that cause blight in legume crops), A. alternata (that causes leaf spot in numerous plant hosts) and L. maculans (that causes blackleg on Brassica spp.). It is not possible to compare the potency of Drr230a against the target fungi herein tested and other affected fungi previously described because of lack of previous literature $\mathrm{IC}_{50}$ data available. Nevertheless, the previously reported antifungal activities of Drr230a expressed in transgenic plants is compatible with the herein presented data. Furthermore, the present data demonstrates that the recombinant rDrr230a expressed in yeast retained its antimicrobial property, interestingly against different fungal species as previously tested and with remarkable high potency against $C$. gossypii var. cephalosporioides.

The effect of extra residues upon antimicrobial activity of recombinant defensins is a case-wise issue. For instance, Kant et al. (2009) showed a minor deleterious effect of 6xHis-tag upon the antifungal activity of the defensin PDC1 against $F$. graminearum. Nevertheless, the activity of the defensin Psd1 against Aspergillus niger, a saprophytic fungus that causes post-harvest black mold in fruits and vegetables, was abolished in the presence of the four leftover residues from the Kex 2 cleavage (EAEA) at the $\mathrm{N}$-terminal of the recombinant protein (Cabral et al. 2003). In spite of the fact that $\mathrm{rDrr} 230 \mathrm{a}$ expressed in yeast has extra residues, due to the Kex 2 cleavage site left over (EAEA) and EcoRI site $(\mathrm{EF})$ at the $\mathrm{N}$-terminus and the presence of 6xHis-tag at the C-terminus (Fig. 1), the antifungal activity of rDrr230a was considerably retained, what is indicated by the remarkable high antimicrobial efficiency $\left(\mathrm{IC}_{50} 0.84 \mu \mathrm{M}\right)$ against $C$. gossypii var. cephalosporioides (Fig. 4).

There are several reports of plant defensins transgenically expressed in plants for protection against pathogenic fungi (De Bondt et al. 1999; Gao et al. 2000; Parashina et al. 2000; Chen et al. 2002, 2006; Park et al. 2002; Chan et al. 2005; Zhu et al. 2007; Anuradha et al. 2008; Choy et al. 2009; Kovalskaya and Hammond 2009; Abdallah et al. 2010; Jha and Chattoo 2010), including the Drr230a defensin, which is object of the present study (Wang and Nowak 1999; Wang and Fristensky 2001; Lai et al. 2002). Nonetheless, to our knowledge, this is the first report of a plant defensin active against $P$. pachyrhizi, $F$. tucumaniae and C. gossypii var. cephalosporioides, which are relevant tropical phytopathogenic fungi of soybean and cotton crops. Since there is neither satisfactory chemical control nor natural sources of resistance against $P$. pachyrhizi, F. tucumaniae and C. gossypii var. cephalosporioides, these results point to rDrr230a as a promising tool for the development of transgenic soybean and cotton plants against this set of impacting tropical diseases.

\section{Conclusions}

The successful expression and purification of the defensin rDrr230a by using $P$. pastoris yeast system, as well as the antimicrobial activity of rDrr230a against impacting cotton and soybean pathogenic fungi was demonstrated in this article. Notably it was demonstrated the inhibition of fungal growth and spore germination of the economically important phytopathogenic fungi $F$. tucumaniae, $P$. pachyrhizi and C. gossypii var. cephalosporioides, which cause soybean sudden death syndrome, Asian soybean rust and cotton ramulosis, respectively. The data herein presented indicate moderate activity of $\mathrm{rDrr} 230$ a against $F$. tucumaniae and high potency against $C$. gossypii var. cephalosporioides. rDrr230a also drastically decreased the severity of Asian soybean rust. Moreover, rDrr230a affects the development of the three target fungi tested since spore germination. These results reveal the potential of rDrr230a for plant genetic engineering to control relevant tropical fungal diseases of cotton and soybean, for which there are 
neither satisfactory chemical control nor resistant varieties commercially available.

Acknowledgments The authors thank Dr. Pierre R. Fobert (National Research Council Canada, Plant Biotechnology Institute) for kindly providing the $d r r 230 a$ gene, Dr. Leila Costamilan (Embrapa Trigo) and Dr. Nelson Dias Suassuna (Embrapa Algodão) for providing fungal isolates. The authors are grateful for the scientific support, technical assistance and critical review of the manuscript performed by Dr. Thales Lima Rocha (Embrapa Recursos Genéticos e Biotecnologia). Authors thank as well Thiago de Jesus Costa (Universidade de Brasília) and João Victor Mendanha Costa (Universidade Católica de Brasília) for the technical support and Sônia Báo (Universidade de Brasília) who provided facilities at the Laboratory of Electron Microscopy. They also thank Dr. Andrew Murray (Embrapa Recursos Genéticos e Biotecnologia) for comments and suggestions on the English language review done of the manuscript. Thanks to FINEP, CNPq, CAPES and Embrapa for financial support.

\section{Compliance with ethical standards}

Conflict of interest The authors declare no financial or commercial conflict of interest.

Open Access This article is distributed under the terms of the Creative Commons Attribution 4.0 International License (http:// creativecommons.org/licenses/by/4.0/), which permits unrestricted use, distribution, and reproduction in any medium, provided you give appropriate credit to the original author(s) and the source, provide a link to the Creative Commons license, and indicate if changes were made.

\section{References}

Abdallah NA, Shah D, Abbas D, Madkour M (2010) Stable integration and expression of a plant defensin in tomato confers resistance to Fusarium wilt. GM Crops 1-5:344-350

Ahuja I, Kissen R, Bones AM (2012) Phytoalexins in defense against pathogens. Trends Plant Sci 2:73-90

Almeida MS, Cabral KS et al (2001) cDNA cloning and heterologous expression of functional cysteine-rich antifungal protein Psd1 in the yeast Pichia pastoris. Arch Biochem Biophys 395:199-207

Anuradha S, Divya K, Jami SK, Kirti PB (2008) Transgenic tobacco and peanut plants expressing a mustard defensin show resistance to fungal pathogens. Plant Cell Rep 27:1777-1786

Aoki T, O’donell K, Homma Y, Lattanzi AR (2003) Sudden-death syndrome of soybean is caused by two morphologically and phylogenetically distinct species within the Fusarium solani species complex $-F$. virguliforme in North America and $F$. tucumaniae in South America. Mycologia 95:660-684

Bednarek P (2012) Chemical warfare or modulators of defense responses-the function of secondary metabolites in plant immunity. Curr Opin Plant Biol 15:407-414

Bloch C Jr, Richardson M (1991) A new family of small (5 kDa) protein inhibitors of insect $\alpha$-amylases from seeds or sorghum (Sorghum bicolor (L) Munch) have sequence homologies with wheat $\gamma$-purothionins. FEBS Lett 279:101-104

Cabral KMS, Almeida MS, Valente AP, Almeida FCL, Kurtenbach E (2003) Production of the active antifungal Pisum sativum defensin 1 (Psd1) in Pichia pastoris: overcoming the inefficiency of the STE13 protease. Protein Expr Purif 31:115-122
Carvalho AO, Gomes VM (2009) Plant defensins-prospects for the biological functions and biotechnological properties. Peptides 30:1007-1020

Chan YL, Prasad V et al (2005) Transgenic tomato plants expressing an Arabidopsis thionin (Thi2.1) driven by fruit-inactive promoter battle against phytopathogenic attack. Planta 221:386-393

Chen KC, Lin CY et al (2002) Cloning and characterization of a cDNA encoding an antimicrobial protein from mung bean seeds. Bot Bull Acad Sin 43:251-259

Chen SC, Liu AR, Zou ZR (2006) Overexpression of glucanase gene and defensin gene in transgenic tomato enhances resistance to Ralstonia solanacearum. Russia J Plant Physiol 53:756-763

Choy MS, Kim YH et al (2009) Expression of Br D1, a plant defensin from Brassica rape, confers resistance against brown plant hopper (Nilaparvata lugens) in transgenic rices. Mol Cells 28:131-137

De Bondt A, Zaman S et al (1999) Genetic transformation of apple (Malus pumila Mill.) for increased fungal resistance: in vitro antifungal activity in protein extracts of transgenic apple expressing Rs-AFP2 or AceAMP1. Acta Hort 484:565-570

de Zélicourt A, Letousey P et al (2007) Ha-DEF1, a sunflower defensin, induces cell death in Orobanche parasitic plants. Planta 226:591-600

Demain AL, Vaishnav P (2009) Production of recombinant proteins by microbes and higher organisms. Biotechnol Adv 27:297-306

Fickers P (2014) Pichia pastoris: a workhorse for recombinant protein production. Curr Res Microbiol Biotechnol 2:354-363

Gao AG, Hakimi SM et al (2000) Fungal pathogen protection in potato by expression of a plant defensin peptide. Nat Biotechnol 18:1307-1310

Godoy CV, Koga LJ, Canteri MG (2006) Diagrammatic scale for assessment of soybean rust severity. Fitopatol Bras 31:63-68

Habib H, Fazili KM (2007) Plant protease inhibitors: a defense strategy in plants. Biotechnol Mol Biol Rev 2:68-85

Horbach R, Navarro-Quesada AR, Deising HB (2011) When and how to kill a plant cell: infection strategies of plant pathogenic fungi. J Plant Physiol 168:51-62

Jha S, Chattoo BB (2010) Expression of a plant defensin in rice confers resistance to fungal phytopathogens. Transg Res 19:373-384

Jrchen J, Hongchen G, Chinghsu H, Shingli S, Sanchen C (2004) Cloning and functional expression of a mungbean defensin $\mathrm{VrD} 1$ in Pichia pastoris. Agric Food Chem 52:2256-2261

Kant P, Liu W, Peter PK (2009) PDC1, a corn defensin peptide expressed in Escherichia coli and Pichia pastoris inhibits growth of Fusarium graminearum. Peptides 30:1593-1599

Kovalskaya N, Hammond RW (2009) Expression and functional characterization of the plant antimicrobial snakin-1 and defensin recombinant proteins. Protein Expr Purif 63:12-17

Kristensen AK, Brunstedt J et al (1999) Processing, disulfide pattern, and biological activity of a sugar beet defensin, AX2, expressed in Pichia pastoris. Protein Expr Purif 16:377-387

Lai FM, DeLong C, Mei K, Wignes T, Fobert PR (2002) Analysis of the DRR230 family of pea defensins: gene expression pattern and evidence of broad host-range antifungal activity. Plant Sci 163:855-864

Lay FT, Anderson MA (2005) Defensins-components of the innate immune system in plants. Curr Protein Pept 6:85-101

Lobo DS, Pereira IB et al (2007) Antifungal Pisum sativum defensin 1 interacts with Neurospora crassa cyclin F related to the cell cycle. Biochemistry 46:987-996

Melo FR, Rigden DJ, Franco OL, Mello LV, Ary MB, Grossi de Sa MF, Bloch C Jr (2002) Inhibition of trypsin by cowpea thionin: characterization, molecular modeling, and docking. Proteins 48:311-319

Mendez E, Moreno A et al (1990) Primary structure and inhibition of protein synthesis in eukaryotic cell-free system of a novel

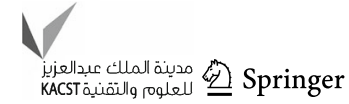


thionin, gamma-hordothionin, from barley endosperm. Eur J Biochem 194:533-539

Mendez E, Rocher A et al (1996) Primary structure of omegahordothionin, a member of a novel family of thionins from barley endosperm, and its inhibition of protein synthesis in eukaryotic and prokaryotic cell-free systems. Eur J Biochem 239:67-73

Muthamilarasan M, Prasad M (2013) Plant innate immunity: an updated insight into defense mechanism. J Biosci 38:433-449

Parashina EV, Serdobinskii LA et al (2000) Genetic engineering of oilseed rape and tomato plants expressing a radish defensin gene. Russ J Plant Physiol 47:417-423

Park HC, Kang YH et al (2002) Characterization of a stamen-specific cDNA encoding a novel plant defensin in Chinese cabbage. Plant Mol Biol 50:57-68

Pelegrini PB, Lay FT, Murad AM, Anderson MA, Franco OL (2008) Novel insights on the mechanism of action of $\alpha$-amylase inhibitors from the plant defensin family. Proteins 73:719-729

Portieles R, Ayra C et al (2010) NmDef02, a novel antimicrobial gene isolated from Nicotiana megalosiphon confers high-level pathogen resistance under greenhouse and field conditions. Plant Biotechnol 8:678-690

Rojas CM, Senthil-Kumar M, Tzin V, Mysore KS (2014) Regulation of primary plant metabolism during plant-pathogen interaction and its contribution to plant defense. Front Plant Sci 10:5-17

Schagger H, Von Jagow G (1987) Tricine-sodium dodecyl sulfatepolyacrylamide gel electrophoresis for the separation of proteins in the range from 1 to $100 \mathrm{kDa}$. Anal Biochem 166:368-379

Seo HH, Park S et al (2014) Overexpression of a defensin enhances resistance to a fruit-specific anthracnose fungus in pepper. PLoS ONE 9:e97936

Song X, Wang J, Wu F, Li X, Teng M, Gong W (2005) cDNA cloning, functional expression and antifungal activities of a dimeric plant defensin SPE10 from Pachyrhizus erosus seeds. Plant Mol Biol 57:13-20
Spelbrink RG, Dilmac N et al (2004) Differential antifungal and calcium channel-blocking activity among structurally related plant defensins. Plant Physiol 135:2055-2067

Towbin H, Staehelin T, Gordon J (1979) Electrophoretic transfer of proteins from polyacrylamide gels to nitrocellulose sheetsprocedure and some applications. PNAS 76:4350-4354

Vassileva A, Chugh DA (2001) Effect of copy number on the expression levels of hepatitis B surface antigen in the methylotrophic yeast Pichia pastoris. Protein Expr Purif 21:71-80

Vijayan S, Guruprasad L, Kirti PB (2008) Prokaryotic expression of a constitutively expressed Tephrosia villosa defensin and its potent antifungal activity. Appl Microbiol Biotechnol 80:1023-1032

Wang YP, Fristensky B (2001) Transgenic canola lines expressing pea defense gene DRR206 have resistance to aggressive blackleg isolates and to Rhizoctonia solani. Mol Breed 8:263-271

Wang Y, Nowak G (1999) Constitutive expression of pea defense gene DRR206 confers resistance to blackleg (Leptosphaeria maculans) disease in transgenic canola (Brassica napus). Mol Plant Microbe Interact 12:410-418

Wijaya R, Neumann GM, Condron R, Hughes AB, Polya GM (2000) Defense proteins from seed of Cassia fistula include a lipid transfer protein homologue and a protease inhibitor plant defensin. Plant Sci 159:243-255

Wong JH, Ng TB (2005) Sesquin, a potent defensin-like antimicrobial peptide from ground beans with inhibitory activities toward tumor cells and HIV-1 reverse transcriptase. Peptides 26:1120-1126

Ye XY, Ng TB (2001) Peptides from pinto bean and red bean with sequence homology to cowpea 10-kda protein precursor exhibit antifungal, mitogenic, and HIV-1 reverse transcriptase-inhibitory activities. Biochem Biophys Res Commun 285:424-429

Zhu YJ, Agbayani R, Moore PH (2007) Ectopic expression of Dahlia merckii defensin DmAMP1 improves papaya resistance to Phytophthora palmivora by reducing pathogen vigor. Planta 226:87-97 